\title{
Komposisi Proksimat Pada Tiga Varietas Tepung Labu Kuning (Cucurbita Sp)
}

\section{Proximate Composition Of Three Varieties Of Pumpkin Flour (Cucurbita Sp)}

\author{
Mardiah $^{1 a}$, Tiana Fitrilia², Sri Widowati ${ }^{3}$, Sumi Fitri Andini ${ }^{2}$
}

1Program Studi Magister Teknologi Pangan,Sekolah Pascasarjana, Universitas Djuanda Bogor, 2Program Studi Teknologi Pangan, Fakultas Ilmu Pangan Halal, Universitas Djuanda Bogor. ${ }^{3}$ Balai Besar Penelitian dan Pengembangan Pasca Panen Pertanian, Badan Penelitian dan Pengembangan

Pertanian

aKorespondensi:Mardiah, E-mail: mardiah@unida.ac.id

(Diterima oleh Dewan Redaksi : 15 - 03 - 2019)

(Dipublikasikan oleh Dewan Redaksi : 08 - 04 - 2020)

\begin{abstract}
Pumpkin is a horticultural product that contains many components of nutrients. Making pumpkin flour is expected to extend the shelf life and can be widely used in food product applications. This study aims to make flour from three varieties of pumpkin (Pumpkin, Kabocha and Butternut) and than knowing the proximate composition of each pumpkin flour. The methode used in making flour was started with soaking pumpkin in sodium metabisulfite and drying using Tray Dryer. The results showed that the proximate composition of Pumpkin, Kabocha and Butternut sequentiall had water content value $14.18 \% ; 11.02 \%$ and $13.28 \%$, ash content $8.05 \% ; 10.0 \%$ and $8.88 \%$, fat content $4.51 \% ; 1.58 \%$ and $1.55 \%$, protein content $11.56 \% ; 14.74 \%$ and $7.32 \%$, carbohydrate $61.71 \% ; 62.62 \%$ and $68.97 \%$ and energy value $333.64 \mathrm{kal} ; 323.61 \mathrm{kal}$ and $319.12 \mathrm{kal}$.
\end{abstract}

Keywords: Pumpkin, pumpkin flour, proximate

\begin{abstract}
ABSTRAK
Labu kuning merupakan produk hortikultura yang mengandung banyak komponen zat gizi. Pembuatan tepung dari labu kuning diharapkan dapat memperpanjang masa simpan dan dapat dimanfaatkan secara luas pada aplikasi produk pangan. Tujuan dari penelitian ini yaitu membuat tepung dari tiga varietas labu kuning (Labu parang, Kabocha dan Butternut) serta mengetahui komposisi proksimat dari masing-masing tepung labu kuning. Metode pembuatan tepung diawali dengan merendam labu kuning dalam larutan natrium metabisulfit dan dilakukan pengeringan menggunakan Tray Dryer. Hasil penelitian menunjukkan bahwa komposisi proksimat labu parang, kabocha dan butternut berturut-turut memiliki kadar air 14.18\%; $11.02 \%$ dan 13.28\%, kadar abu 8.05\%; 10.0\% dan 8.88\%, kadar lemak 4.51\%; 1.58\% dan $1.55 \%$, kadar protein $11.56 \% ; 14.74 \%$ dan $7.32 \%$, kadar karbohidrat $61.71 \%$; 62.62\% dan 68.97\% serta nilai energi $333.64 \mathrm{Kal}$; $323.61 \mathrm{Kal}$ dan 319.12 Kal.
\end{abstract}

Kata kunci: Labu kuning,tepung labu kuning, proksimat

Mardiah, Tiana Fitrilia, Sri Widowati, Sumi Fitri Andini. 2020. Komposisi Proksimat pada Tiga Varietas Tepung Labu Kuning (Cucurbita sp). Jurnal Agroindustri Halal 6(1): 97 - 104. 


\section{PENDAHULUAN}

Tanaman labu kuning memiliki 27 spesies yang dapat tumbuh di daerah tropis ataupun subtropis (Hazra et al. 2007). Penyebaran labu kuning di Indonesia telah merata. Menurut Igfar (2012), penanaman dan pemeliharaan labu kuning terbilang mudah serta dapat diandalkan untuk menjadi sumber pangan.

Pemanfaatan labu kuning saat ini masih sebatas pengolahan pangan tradisional seperti dodol, kolak, asinan, manisan, sayur, sup, puding, kue basah dan makanan lain dengan umur simpan singkat dan distribusi terbatas (Rahmawati et al. 2014). Pemanfaatan yang kurang optimal terlihat dari rendahnya masyarakat yang mengkonsumsi labu kuning yaitu kurang dari 5 kg per kapita pertahun (Igfar 2012). Padahal labu kuning yang merupakan salah satu sumber bahan pangan memiliki kandungan gizi cukup lengkap dalam pemenuhan gizi harian.

Berdasarkan data yang ada pada Daftar Komposisi Bahan Pangan Depkes RI (2005), bahwa dalam $100 \mathrm{~g}$ buah labu kuning segar mengandung protein $1.1 \mathrm{~g}$, lemak $0.3 \mathrm{~g}$, karbohidrat $6.6 \mathrm{~g}$, air $9.1 \mathrm{~g}$, kalsium $45 \mathrm{mg}$, fosfor $64 \mathrm{mg}$, besi $1.4 \mathrm{mg}$, vitamin A $180 \mathrm{sI}$, Vitamin B $0.08 \mathrm{mg}$ dan Vitamin C $5.2 \mathrm{mg}$. Adanya kandungan gizi pada labu kuning, diharapkan labu kuning dapat dimanfaatkan secara luas oleh masyarakat. Menurut Hamdi et al. (2017), masa simpan labu kuning sekitar 6 bulan atau lebih tergantung pada penyimpanannya. Oleh karena itu, untuk memperpanjang masa simpan labu kuning dan kemudahan dalam aplikasinya perlu dilakukan penepungan labu kuning.

Labu kuning yang dibuat tepung memiliki warna putih kekuningan dengan butiran yang halus serta memiliki bau khas seperti labu kuning. Menurut Que et al. (2008), produk tepung memiliki masa simpan yang lama dan dapat diolah lebih lanjut menjadi berbagai produk. Namun pada proses pengolahan tepung dapat menyebabkan kandungan gizi dalam bahan mengalami penurunan (Manira et al. 2011).
Menurut Purwanto et al. (2013), proses produksi labu kuning menadi tepung dapat menyebabkan terjadinya reaksi Browning. Salah satu cara dalam pencegahan perubahan warna dan penurunan zat gizi adalah merendam labu kuning dalam natrium metabisulfit. Menurut Slamet (2010), perendaman labu kuning dalam natrium metabisulfit menyebabkan warna tepung yang dihasilkan lebih cerah.

Purwanto et al. (2013) melakukan penelitian tentang labu kuning yang direndam dengan natrium metabisulfit pada berbagai konsentrasi dalam produksi tepung. Konsentrasi terbaik adalah $0.3 \%$ yang memiliki nilai tertinggi pada daya serap air, kelarutan, lightness, daya dispersi, protein dan lemak. Penelitian Mardiah et al. (2019) perendaman potongan labu kuning dengan natrium metabisulfit $0.3 \%$ selama 10 menit sebelum dikeringkan memberikan warna tepung yang lebih cerah, kadar air rendah (8.48\%) dan kadar beta karoten tertinggi ( $4.29 \mathrm{mg} / \mathrm{g})$.

Tujuan penelitian ini adalah membuat tepung dari tiga varietas labu kuning yaitu labu parang, kabocha dan butternut dengan perendaman menggunakan natrium metabisulfit. Hal ini karena ketiga jenis ini banyak ditemukan di daerah Bogor sehingga diperlukan informasi dan data mengenai kandungan kimia dan gizi ketiga bahan tersebut ketika dijadikan bahan tepung.

\section{MATERI DAN METODE}

\section{Labu Kuning}

Labu kuning (Cucurbita sp) yang merupakan famili Cucurbitaceae yang bersifat menjalar. Perkembangbiakan labu kuning teradi secara aseksual melalui biji.

Labu kuning yang telah dipetik biasanya memiliki masa simpan sekitar 6 bulan dan hal ini dipengaruhi oleh tingkat kematangan buahnya. Gambar 1 merupakan varietas labu kuning (Cucurbita $s p$ ) yang digunakan dalam penelitian. 


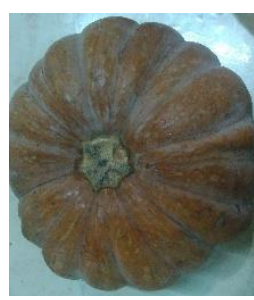

a

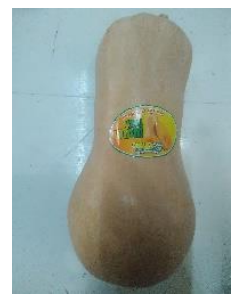

b

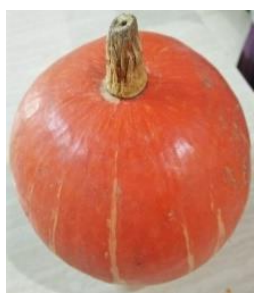

C
Gambar 1. Tiga varietas labu kuning. a) Labu Parang, b) Kabocha, c) Butternut

\section{Tepung Labu Kuning}

Tepung labu kuning diperoleh dengan cara pengeringan. Mutu tepung jika dilihat secara fisik sangat dipengaruhi oleh bahan maupun suhu pengeringan yang diterapkan. Labu yang sudah tua memiliki kadar gula yang tinggi sehingga akan memberikan pengaruh pada mutu tepung yang dihasilkan.

Menurut Hendrasty (2003), tepung yang dihasilkan dari bahan dengan kadar gula tinggi dan dilakukan pengeringan dengan suhu tinggi, akan menyebabkan penggumpalan dan bau karamel pada tepung. Berdasarkan penelitian yang dilakukan oleh See et al. (2007) labu kuning (Cucurbita moschata) yang telah dibuat tepung memiliki kadar air $10.96 \%$, lemak $0.80 \%$, protein $9.65 \%$, karbohidrat $72.41 \%$, abu $5.37 \%$, serat $0.81 \%$ dan beta karoten $4857.6 \mu \mathrm{g}$.

\section{Tray Drying}

Tray drying adalah salah satu metode pengeringan yang dapat diaplikasikan pada bahan pangan. Prinsip utama dari tray dryer yaitu dapat beroperasi dalam keadaan vakum dan pemanasan tidak langsung. Purwanto et al. (2013) mengeringkan labu kuning (Cucurbita maxima) menggunakan Tray Dryer pada suhu $60^{\circ} \mathrm{C}$ dan membutuhkan waktu selama 8-9 jam.

\section{Bahan dan Alat}

Bahan-bahan dalam penelitian yaitu tiga varietas labu (Labu Parang, Kabocha dan Butternut) yang diperoleh dari Kebun Bukit Unggul Lembang dan POLBANGTAN Bogor, air, natrium metabisulfit $\left(\mathrm{Na}_{2} \mathrm{~S}_{2} \mathrm{O}_{5}\right)$ dan bahan-bahan analisis lainnya.

Alat-alat terdiri atas alat gelas, neraca analitik, tray dryer, discmill, ayakan 60 mesh, oven, cawan porselen, desikator, labu Kjeldahl, alat titrasi.

\section{Waktu dan Tempat Penelitian}

Waktu Penelitian dimulai dari Juli sampai Oktober 2019. Tempat penelitian yaitu Laboratorium Pengolahan Pangan dan Laboratoriun Sains Universitas Djuanda.

\section{Pembuatan Tepung Labu Kuning}

Tiga varietas labu kuning digunakan dalam penelitian ini. Pemilihan kematangan ketiga jenis labu didasarkan pada uji kadar gula dengan alat refraktometer berkisar anatara 7 sampai dengan $9^{\circ}$ Brix. Masingmasing labu dilakukan pengupasan dan pembuangan biji. Kemudian dilakukan pencucian menggunakan air bersih dan mengalir serta dikecilkan ukurannya menjadi 2-3 $\mathrm{mm}$.

Labu kuning yang telah di potongpotong, dimasukkan ke dalam larutan natrium metabisulfit. Selanjutnya dikeringkan dengan alat pengering berupa Tray Dryer pada suhu $60{ }^{\circ} \mathrm{C}$ selama 8 jam. Setelah dikeringkan, labu kuning dilakukan penepungan dan diayak menggunakan ayakan berukuran 60 mesh. Gambar 2 merupakan tahapan dalam mengolah labu kuning menadi produk tepung.

\section{Rancangan Percobaan}

Penelitian ini menggunakan Rancangan Acak Lengkap (RAL) satu faktor. Faktornya adalah varietas labu kuning dengan tiga taraf perlakuan (labu parang, kabocha dan butternut). Model matematis yang digunakan yaitu :

$$
\mathrm{Y}_{\mathrm{ij}}=\mu+\tau_{\mathrm{i}}+\varepsilon_{\mathrm{ij}}
$$

Keterangan :

$\mathrm{Y}_{\mathrm{ij}}=$ Nilai pengamatan pada varietas labu kuning (parang, kabocha dan butternut) ke-i, ulangan ke-j

$\mu=$ Rataan umum

$\tau_{\mathrm{i}}=$ Nilai tambah varietas labu kuning ke-i

$\varepsilon_{\mathrm{ij}}=$ Galat percobaan (nilai tambah pengaruh acak pada varietas labu kuning ke-i, dan ulangan ke-j) 


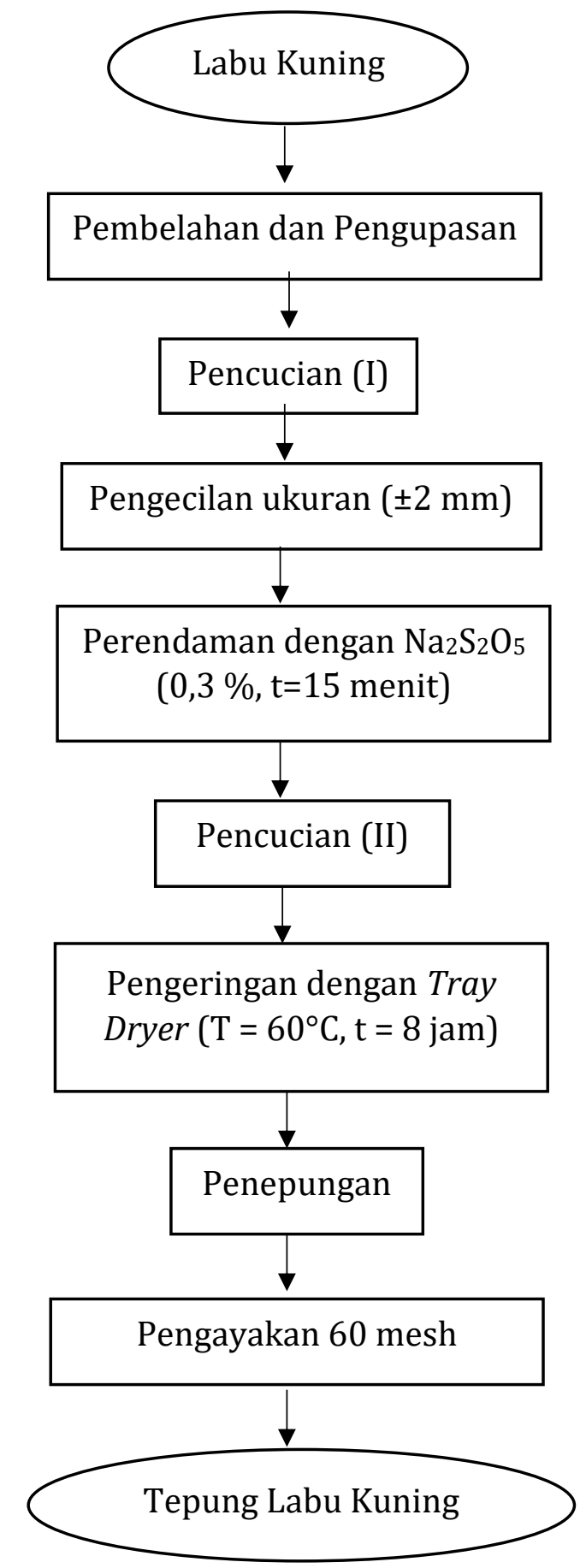

Gambar 2. Pembuatan tepung labu kuning

(Modifikasi Purwanto et al., 2013)

\section{Analisis Produk}

Analisis produk terdiri atas kadar air (AOAC 2005), kadar abu (AOAC 2005), lemak (AOAC 2005), protein (AOAC 2005) dan karbohidrat (Winarno 2002).

\section{Analisis Data}

Analisis data menggunakan program Statistical Product and Service Solution (SPSS). Uji statistik yang digunakan adalah uji sidik ragam ANOVA dan jika nilai $\mathrm{p}<0.05$ dilakukan ui lanjut Duncan Multiple Range Test (DMRT) pada $\alpha=0.05$.

\section{HASIL DAN PEMBAHASAN}

Tepung dibuat dengan cara pengeringan labu kuning menggunakan alat berupa Tray Dryer. Menurut Kristiani (2016), penggunaan Tray Dryer karena sesuai dengan karakteristik bahan yang dikeringkan, bahan dengan padatan yang banyak yaitu labu kuning. Tabel 1 merupakan komposisi proksimat dari tiga varietas labu kuning (Labu Parang, Kabocha dan Butternut) .

\section{Kadar Air}

Menurut Warkoyo (2007), penentuan parameter kadar air pada produk tepung menjadi syarat penting untuk menentukan mutu tepung tersebut terutama terkait keamanan produk yang disimpan dalam waktu lama. Kadar air menyatakan jumlah kandungan air yang terdapat pada suatu bahan pangan (Kusnandar 2010). Berdasarkan SNI 01-3751-2009, tepung terigu memiliki kadar air maksimal $14.5 \%$. Tepung jagung $10.0 \%$, tepung singkong $12.0 \%$ dan tepung beras 13\% (Honestin 2007). Kadar air pada tepung labu kuning hasil penelitian masih dalam kisaran tepungtepung tersebut.

Berdasarkan Tabel 1, terlihat bahwa varietas labu kuning memberikan pengaruh terhadap parameter kadar air tepung. Perbedaan secara nyata terdapat pada Tepung Kabocha dengan butternut dan labu parang, akan tetapi tepung labu parang dengan butternut hasil analisisnya tidak berbeda secara nyata. Nilai kadar air terendah dimiliki oleh kabocha (Cucurbita maxima L.) yaitu 11.02\%. Penelitian sebelumnya yang dilakukan oleh Purwanto et al. (2013), menunjukkan bahwa tepung labu kuning (Cucurbita maxima) yang diperoleh dari hasil perendaman labu dengan natrium 
metabisulfit 0.3\% memiliki kadar air 10.15\%. Hal ini memperlihatkan kadar air hasil penelitian masih lebih tinggi dari penelitian terdahulu.

Tabel 1. Komposisi Proksimat Tepung Labu Kuning Tiga Varietas (Basis Basah)

\begin{tabular}{llll}
\hline Parameter (satuan) & Labu Parang & Kabocha & Butternut \\
\hline Kadar air (\%) & $14.18 \pm 0.20^{\mathrm{a}}$ & $11.02 \pm 0.34^{\mathrm{b}}$ & $13.28 \pm 0.35^{\mathrm{a}}$ \\
Kadar abu (\%) & $8.05 \pm 0.31^{\mathrm{b}}$ & $10.04 \% \pm 0.20^{\mathrm{a}}$ & $8.88 \% \pm 0.34^{\mathrm{b}}$ \\
Kadar lemak (\%) & $4.51 \pm 0.21^{\mathrm{a}}$ & $1.58 \% \pm 0.09^{\mathrm{b}}$ & $1.55 \% \pm 0.32^{\mathrm{b}}$ \\
Kadar protein (\%) & $11.56 \pm 0.41^{\mathrm{b}}$ & $14.74 \pm 0.14^{\mathrm{a}}$ & $7.32 \pm 0.32^{\mathrm{c}}$ \\
Kadar karbohidrat (\%) & $61.71 \pm 0.10^{\mathrm{b}}$ & $62.62 \pm 0.32^{\mathrm{b}}$ & $68.97 \pm 0.69^{\mathrm{a}}$ \\
Energi (kal) & $333.64 \pm 0.65^{\mathrm{a}}$ & $323.61 \pm 2.65^{\mathrm{b}}$ & $319.12 \pm 1.14$ \\
& & & $\mathrm{~b}$
\end{tabular}

*Notasi yang sama menunjukkan tidak adanya perbedaan antara ketiga jenis labu

Tepung butternut (Cucurbita moschata) memiliki nilai kadar air sebesar $13.28 \%$. Hasil tersebut lebih tinggi jika dibandingkan dengan kadar air hasil penelitian Prabasini et al. (2013) yaitu $12.23 \%$ dimana tepung yang dihasilkan merupakan hasil perendaman menggunakan natrium metabisulfit dengan konsentrasi sebesar $0.3 \%$. Adanya perbedaan hasil penelitian tersebut bisa disebabkan oleh perbedaan lama waktu perendaman dan atau tingkat kematangan labu.

\section{Kadar Abu}

Kadar abu merupakan ukuran dari besarnya zat-zat anorganik yang terkandung dalam bahan dan merupakan sisa hasil pembakaran suatu bahan. Menurut Purba (2008), suatu bahan memiliki jenis dan jumlah kadar abu yang tidak sama.

Berdasarkan hasil kadar abu tepung dari tiga varietas labu kuning, dapat dilihat bahwa varietas kabocha memiliki perbedaan nyata dengan butternut dan labu parang, yakni $10.04 \%$ dan nilai ini paling tinggi dibandingkan dengan dua varietas lainnya. Kadar abu yang ada pada bahan berhubungan dengan kandungan mineral yang terdapat dalam bahan tersebut. Menurut Sudarmadji (2003), proses pengabuan terjadi pada suhu tinggi dimana setiap bahan dapat memiliki suhu pengabuan yang berbeda-beda. Hal ini tergantung dengan komponen yang ada di bahan. Bahan-bahan organik pada proses pembakaran akan terbakar, sementara komponen anorganiknya tidak terbakar sehingga dikatakan sebagai abu (Apriliyanti 2010).

Kadar abu dari hasil analisis ketiga varietas lebih besar dari penelitian yang sudah ada. See et al. (2007) melakukan analisis kimia terhadap kadar abu dari tepung labu kuning yaitu diperoleh sebesar $5.37 \%$. Penelitiannya menggunakan Labu kuning yang berasal dari pasar yang ada di Malaysia dan metode pengeringannya menggunkan Ventilated Dryer. Hal ini menunjukkan bahwa kadar abu pada tepung ang diperoleh dari pengeringan labu kuning dapat dipengaruhi oleh sumber labu kuning tersebut dan metode yang diterapkan dalam proses pembuatan tepung.

\section{Kadar Lemak}

Lemak diperlukan oleh tubuh dalam jumlah tertentu untuk memelihara kesehatan dan dapat diperoleh dari banyak sumber yang mengandung zat makanan tersebut (Prabowo 2010). Hasil oksidasi $1 \mathrm{~g}$ lemak akan menghasilkan energi sebesar 9 kkal, sementara oksidasi $1 \mathrm{~g}$ karbohidrat, energi yang dihasilkan yaitu $4 \mathrm{kkal}$ dan protein 4 kkal, sehingga dapat dikatakan bahwa efektifitas lemak sebagai sumber energi lebih tinggi dibanding sumber yang lain (Winarno 2004).

Tabel 1 pada parameter kadar lemak memperlihatkan perbedaan nyata tepung labu parang dengan tepung kabocha dan 
butternut. Kadar lemak paling tinggi terdapat pada tepung labu parang yaitu 4.51\%. Sedangkan kadar lemak pada tepung kabocha sebesar $1.58 \%$ dan tepung butternut sebesar 1.55\%.

Penelitian terdahulu yang dilakukan oleh Prabasini et al. (2013) tentang tepung labu kuning (Cucurbita moschata) dan Purwanto et al. (2013) tentang tepung Cucurbita maxima, dimana penelitian keduanya sama-sama melakukan perendaman labu kuning dengan natrium metabisulfit $0.3 \%$ diperoleh nilai kadar lemak secara berturut-turut yaitu 3.09\% dan $2.37 \%$. Adanya perbedaan nilai kadar lemak dari hasil penelitian dapat disebabkan oleh sumber bahan baku yang digunakan.

\section{Kadar Protein}

Protein tersusun dari rangkaian asam amino yang dibutuhkan oleh tubuh terutama sebagai zat pembangun. Protein yang merupakan makromolekul dapat ditemukan dalam bahan pangan sebagai sumber asam amino (Andarwulan et al. 2011). Tabel 1 memperlihatkan bahwa varietas labu kuning memberikan pengaruh secara nyata terhadap kandungan/kadar protein pada tepung. Tepung labu parang memiliki kandungan protein rata-rata sebesar $11.56 \%$, kabocha memiliki kandungan protein terbesar dengan rata-rata yaitu $14.74 \%$ dan butternut memiliki kandungan protein terendah dengan rata-rata $7.32 \%$.

Hasil penelitian Kristiani (2016) menunjukkan bahwa kadar protein dari tepung labu parang dengan pra-perlakuan natrium metabisulfit $0.10 \%$ sebagai bahan perendam dan dilakukan perendaman dengan waktu 10 menit menggunakan pengering tray dryer sebesar $8.48 \%$.

Sementara kadar protein dari tepung labu kuning hasil penelitian Purwanto et al. (2013) yang melakukan perendaman labu dengan natrium metabisulfit $0.3 \%$ sebesar $1.55 \%$. Perbedaan kadar protein yang dihasilkan dapat disebabkan oleh jenis labu kuning yang digunakan. Menurut Lolliani (2017), bentuk labu kuning yang bervariasi memberikan nilai kadar protein yang beragam pula.

\section{Kadar Karbohidrat}

Karbohidrat merupakan jenis
makromolekul yang terdapat secara
melimpah di alam. Menurut Sinaga (2012),
karbohidrat memiliki fungsi utama sebagai
sumber energi, namun ada juga senyawa dari
karbohidrat yang merupakan pembentuk
struktur tubuh. Penentuan kandungan
karbohidrat pada suatu bahan pangan pada
penelitian ini menggunakan metode by
difference.

Prinsip metode by difference yaitu menghitung hasil pengurangan 100 dengan nilai kadar air, abu, lemak dan protein. Hasil penelitian pada Tabel 1 memperlihatkan bahwa varietas labu kuning memberikan pengaruh secara nyata terhadap kadar karbohidrat tepung yang dihasilkan. Sementara perbedaan tidak nata terdapat pada

Tepung butternut dengan tepung kabocha dan labu parang, yang menghasilkan kadar karbohidrat tertinggi yaitu 68.97\%. Hal ini disebabkan kandungan gula pada butternut lebih tinggi, ditandai dengan tepung yang dihasilkan agak lengket dan mudah menggumpal.

\section{Nilai Energi}

Nilai energi tepung dari ketiga varietas labu kuning memiliki perbedaan secara nyata. Labu parang memiliki nilai energi tertinggi dibandingkan dengan Kabocha dan Butternut yaitu 333.64 kal. Perhitungan nilai energi didasakan pada nilai kadar lemak, protein dan karbohidrat dalam $100 \mathrm{~g}$ tepung labu kuning.

\section{KESIMPULAN}

Tepung labu kuning dari tiga varietas yaitu Labu Parang, Kabocha dan Butternut memiliki komposisi proksimat yang berbeda. Nilai kadar air dan kadar lemak paling tinggi terdapat pada tepung labu parang. Kadar abu dan kadar protein paling tinggi terdapat pada tepung Kabocha. Sementara kadar karbohidrat paling tinggi terdapat pada tepung Butternut. 


\section{UCAPAN TERIMA KASIH}

Kegiatan penelitian yang dilakukan merupakan bagian dari Tri Dharma Perguruan Tinggi yang melibatkan banyak pihak. Oleh karena itu, penulis mengucapkan terima kasih khususnya kepada Direktorat Jenderal Penguatan Riset dan Pengembangan, Kementerian Riset, Teknologi dan Pendidikan Tinggi yang telah mempercayai program ini untuk dibiayai dan Universitas Djuanda yang telah menfasilitasi untuk keberlangsungan program penelitian.

\section{DAFTAR PUSTAKA}

[AOAC] Association of Official Analytical Chemistry. 2005. Method of Analysis. Washington, D.C.

Andarwulan N, Kusnandar F, Herawati D. 2011. Analisis Pangan. Jakarta: PT. Dian Rakyat

Apriliyanti T. 2010. Kajian sifat fisikokimia dan sensori tepung ubi jalar ungu (Ipomea batatas blackie) dengan variasi proses pengeringan. [Skripsi]. Fakultas Pertanian, Universitas Sebelas Maret, Surakarta.

Direktorat Gizi Depkes RI. 2005. Daftar Komposisi Bahan Makanan. Bhratara Karya Aksara. Jakarta.

Hamdi, Andiyono, Mulyati S. 2017. Pengembangan Bahan Pangan Lokal Labu Kuning (Cucurbita Moschata) Di Kabupaten Sambas. UNES Journal of Agricultural Scienties, 1: 13-32.

Hendrasty HK. 2003. Tepung Labu Kuning Pembuatan dan Pemanfaatanna. Yogyakarta : Kanisius.

Hazra P Mandal AK, Dutta AK, Ram HH. 2007. Breeding Pumpkin (Curcubitamoschata (Duch. Ex Poir.) for Fruit Yield and Other Character. International Journal of Plant Breeding. 1(1): 51-64.

Honestin T. 2007. Karakterisasi sifat fisikokimia tepung ubi jalar. (Ipomoea batatas). [skripsi]. Bogor: Fakultas Teknologi Pertanian, Institut Pertanian Bogor.
Igfar A. 2012. Pengaruh penambahan tepung labu kuning dan tepung terigu terhadap pembuatan biskuit. [Skripsi]. Fakultas Pertanian, Universitas Hasanudin. MakassarFerita I, Tawarati, Syarif Z. 2015. Identifikasi dan Karakterisasi Tanaman Enau (Arenga pinnata) di Kabupaten Gayo Lues. Prosiding Seminar Nasional Masyarakat Biodiversitas Indonesia 1(1): 31-37.

Kristiani Y. 2016. Karakteristik sifat fisikokimia tepung labu kuning (Cucurbita moschata D.) [Skripsi]. Fakultas Teknologi Pertanian, Institut Pertanian Bogor

Kusnandar F. 2010. Kimia pangan. Komponen Pangan. PT. Dian Rakyat. Jakarta.

Lolliani (2017). Variabilitas lima genotipe labu kuning (Cucurbita sp) berdasarkan kandungan nutrisi dari kecamatan danau kembar dan lembah gumanti kabupaten Solok. [Skripsi]. Universitas Andalas.

Manirza, Medikasari, Nurlaili. 2011. Produksi Tepung Ubi Kayu Berprotein : Kajian Pemanfaatan Tepung Kacang Benguk sebagai Sumber Nitrogen Ragi Tempe. Jurnal Teknologi dan Industri Hasil Pertanian 16(1): 74-81.

Mardiah, Andini SF, Fitrilia T, Hakim L Widowati S. 2019. Pra Perlakuan Kimia dan Fisik pada Labu Kuning (Cucurbita sp) terhadap Kadar $\beta$ Karoten. Prosiding Seminar Nasional "Peranan Perguruan Tinggi dalam Pengembangan Keilmuan Abad 21" di Unida tanggal 28 Agustus 2019.

Prabasini H, Ishartani D, Rahadian D. 2013. Kajian sifat kimia dan fisik tepung labu kuning (Cucurbita moschata) dengan perlakuan blanching dan perendaman natrium metabisulfit $\left(\mathrm{Na}_{2} \mathrm{~S}_{2} \mathrm{O}_{5}\right)$. Jurnal Teknosains Pangan 2(2): 93-102.

Purba JH. 2008. Pemanfaatan labu kuning sebagai bahan baku minuman kaya serat. [skripsi]. Fakultas Teknologi Pertanian, Institut Pertanian Bogor, Bogor.

Purwanto CC, Ishartani D, Rahadian D. 2013. Kajian sifat fisik dan Kimia tepung labu 
kuning (Cucurbita maxima) dengan perlakuan blanching dan perendaman natrium metabisulfit $\left(\mathrm{Na}_{2} \mathrm{~S}_{2} \mathrm{O}_{5}\right)$. Jurnal Teknosains Pangan 2(2). ISSN: 2302-0733.

Que F, Mao L, Fang X, Wu T. 2008. Comparison of Hot air-drying and freeze-drying on the physic-chemical properties and antioxidant activities of pumpkin (Cucurbita moschata Duch.) flours. Inter. J. Food Sci. Tech. 43: 1195-1201.

Rahmawati L, Susilo B, Yulianingsih, R. 2014. Pengaruh variasi blanching dan lama perendaman asam asetat $\left(\mathrm{CH}_{3} \mathrm{COOH}\right)$ terhadap karakteristik tepung labu kuning termodifikasi. Jurnal Bioproses Komoditas Tropis, 2(2) : 107-115.

See EF, Wan NWA, Noor AAA. 2007. Physicochemical and sensory evaluation of breads supplemented with pumpkin flour. ASEAN Food Journal 14(2): 123-130.

Sinaga E. 2012. Biokimia Dasar. Jakarta : PT ISFI Penerbitan.

Slamet A. 2010. Pengaruh Perlakuan Pendahuluan Pada Pembuatan Tepung Ganyong (Canna edulis) Terhadap Sifat Fisik Dan Amilografi Tepung Yang Dihasilkan. Agrointek 4(2): 100-103.

Sudarmadji S, Suhardi, Haryono. 2003. Analisis Bahan Makanan dan Pertanian. Penerbit Liberty. Yogyakarta.

Warkoyo. 2007. Studi Ekstraksi Karaginan dari Rumput Laut Euchema cottoni. [Skripsi]. Universitas Muhammadiyah Malang, Malang.

Winarno FG. 2004. Kimia Pangan dan Gizi. Gramedia Pustaka Utama. Jakarta. 